\title{
Interdisciplinary Formation and Social Integration in Present-Day
}

\author{
Vandeí Pinto da Silva1, Joice Ribeiro Machado da Silva',3, Rosane Michelli de Castro1 \\ ${ }^{1}$ Department of Didactics and the Program of Postgraduate on Education in the Faculty of Philosophy and \\ Sciences, University Estadual Paulista "Julio de Mesquita Filho" - UNESP/Marília, São Paulo, Brazil \\ ${ }^{2}$ Education by Program of Postgraduate on Education in the Faculty in the Technology and Sciences, University \\ Estadual Paulista "Julio de Mesquita Filho" - UNESP/Presidente Prudente, São Paulo, Brazil \\ ${ }^{3}$ Technical Area of the Attending Elementary School the Municipal School System in the Marília, São Paulo, \\ Brazil \\ Email:vandeips@uol.com.br, joice.rbr@gmail.com, rosanemichelli@marilia.unesp.br
}

Received 28 August 2015; accepted 9 October 2015; published 13 October 2015

Copyright @ 2015 by authors and Scientific Research Publishing Inc.

This work is licensed under the Creative Commons Attribution International License (CC BY).

http://creativecommons.org/licenses/by/4.0/

(c) (i)

\section{Abstract}

This paper emerges from our researches and educational professional practices in higher education on teacher's formation. The concern is with the interdisciplinary formation of future teachers and the goal is to provide theoretical discussions and practical experiences that support an understanding of the world and its history as close to reality as possible. In the first part, we discussed the concepts of disciplinary and interdisciplinary. We assumed that the reach of current stage of scientific and technological knowledge was due to the specialization of areas and subareas of knowledge in the disciplinary context, particularly in undergraduate and graduate. The side effect of this development is manifested in fragmented conceptions of the world and the individual, especially when disciplinary emphasis is given in stages of basic education, with damage to omnilateral formation, social relations and environmental sustainability. In the second part we discussed formation processes developed in Brazilian graduation courses: the necessary link "content, methodology and teaching practice" and the importance of interdisciplinary dialogue with a view to the formation of individuals able to integrate themselves critically in processes of material and cultural contemporary production. In spite of the official curriculum proposals advocate interdisciplinary formation, evaluative systems in large scale reduce the contents to be evaluated at the teaching of the mother tongue and mathematics, with interference in the school system and the teacher's work. Finally, we question the professor's formation in its historical and social context. We argue that the rescue of individual's formation as a historic person aware of his transformative role involves interdisciplinary formation as condition to a suitable conception of the world and to a social integration of the individual that allows harmonious relationship with himself, others and the world. 


\section{Keywords}

\section{Interdisciplinary, Social Integration, Omnilateral Formation, Contemporary, Humanization}

\section{School, Interdisciplinary and Omnilateral Formation}

In human history, the non-school and school education processes have always sought to comply the objective to integrate individuals between themselves and the social context in which they are inserted. A proper social integration supposes formation for participation in work processes and cultural life, with a goal to insure the provision of material and cultural goods needed for the harmonious relationship of human life in society and the transformation of natural resources in order to preserve their sources and human species itself. However, not always the goal of individuals' social integration has been appropriately achieved in history's course, because in a lot of situations there was a shortage in the supply of basic needs such as food and home.

In front of contradictions of such magnitude, the concept of interdisciplinary formation may represent a breakthrough in the constitution of the formative profile of contemporary man, here conceived as what challenges to synthesize the past experiences and future's projects in present's configuration, in which it is called to live, sometimes inatual way, profaning usual conventionalities (Agamben, 2010).

Referring to "Untimely Considerations" by Nietzsche, Agamben (2010: pp. 58-59, 72) reflects:

"Truly belongs to its time, it is truly contemporary, one that does not coincide perfectly with this, nor it is appropriate to its claims and it is, accordingly, inatual; but exactly why, exactly through this shift and this anachronism, it is able, more than others, to understand and apprehend your time. [...] This means that the contemporary is not only one who, realizing the dark of present, apprehends the resolute light; it is also the one who, dividing and interpolating the time, is up to turn it and put it in relation to other times, to read a history in inedited way, "citing it" according to a need that does not comes in any way of your choice, but a requirement to which he cannot answer."

In the course of modernity, the history of education records emphasis on technical formation, trademark of capitalist society. The advance of science, especially in its technological perspective, generated products with a high degree of specialty, capable of supplying different types of human needs. Humanity finds itself seduced by the benefits and possibilities of progress and yet large portions of the world population has no access enjoying the goods produced, it is given approval to the modus operandi of the capitalist production system for its vaunted efficiency. It should be recognized that the scientific and technological progress was only possible thanks to investment in research in the disciplinary area and the installment of technical workers' activities. In the context of sidelined general formation, the biggest loss was for semi-skilled workers, which have reduced their formation to elementary technical dimension.

With the complexity of materials production processes occurred since the industrial revolution and, more recently, the intensification of exchanges between the different people around the world, the modality of school education, globally, gained prominence in the face of other modalities of education, especially in two aspects: increase years of schooling for basic formation of every individual and universal access to school.

The emphasis on school as an educational institution, very characteristic of contemporary society, causes questions about the type of training afforded by the school and whether it is consistent with the historical, social and cultural requirements claiming an individual capable of producing material and cultural goods in a creative way and with a high degree of specialty.

The investment in disciplinary has as a side effect the formation of incomplete individuals, not only under the perspective of their capacity to work, but also in other dimensions of their existence: understanding oneself, others and the world. Therefore, it is necessary to reflect on the concept of interdisciplinary and its importance in educated formation.

The concept of interdisciplinary formation implies preserving the disciplinary: inter disciplinary, as the term evokes. The interdisciplinary perspective places the disciplinary in all the other disciplines and areas of knowledge, in a dialogical and integrated relationship that facilitates individuals a better understanding of things. In interdisciplinary, the disciplinary is not denied nor dissolved, but it’s not made absolute. 
Rios (2008: p. 58) places the issue of globalization and its consequences on the fragmentation of knowledge, its massification and homogeneity. In this context, he advocates the consideration of the differences and specificities of knowledge and practice in an interdisciplinary and collective work.

"It is necessary, therefore, to reflect on the meaning of interdisciplinary. There can be no interdisciplinary if you do not have at first disciplinary, very specifically talking.

It is common to speak of interdisciplinary in a wrong way, as if it was a mix of work: we are going to do an interdisciplinary work, then join the disciplines of Portuguese, Mathematics, Geography, History around a theme, and then it's done, we have interdisciplinary. Actually, it's much more complex: there is interdisciplinary when it comes truly of a dialogue, or a partnership, which is exactly the difference, the specificity of action of groups or individuals who want to achieve common goals, which "play" in different positions on the same team.”

In the case of school curricula, the denial of disciplinary knowledge can generate an emptying of formation content, affects the overall vision and impoverishes formation, making it incompatible with the requirements posed by the contemporary world. But when the disciplinary contents are studied in isolation or attach studies in a single field of knowledge, gaps, limits and misunderstandings occur. The perspective of interdisciplinary formation, if appropriately implemented in school formation, may contribute to the formation of more complete subject, able to withstand the onslaughts of high productivity and exacerbated and predatory consumption.

The interdisciplinary perspective is shaped primarily in the curriculum and building the Pedagogical Political Project of school, which, in turn, are guided by the definition of school's social role in shaping the individual. In this sense, selections of content, methodologies and strategies of the teaching should be related between disciplinary, interdisciplinary and transdisciplinary dimensions. These dimensions are manifested socially in the forms of organization of life and its material and intellectual production. In real life, the phenomena are perceived by the individual as elements of an interconnected whole, never alone. Facts of reality reveal to him in a transdiciplinary way and in many cases chaotically. To establish connections between facts and understand the organic of the whole is the challenge posed to the man who seeks to recognize its place as a historical individual.

We arrived at a moment when the production process in which the emphasis on formation for material and non-material productive work can no longer be unilaterally presented as school function. The school's goals should transcend the preparation target for the job, including omnilateral human formation, from all sides, and it includes both intellectual, body and technology formation (Marx \& Engels, 2004).

In absence of education of workers and excessive unilateralization of its formation, in 1868, Marx, in the Instructions to delegates of the Provisional Central Council Londoner, the First Congress of the International Workers Association (IWA), emphasized the significance of the omnilateral formation, explaining his concept of education (Marx \& Engels, 2004: p. 68).

"By education we understand three things:

1) Intellectual education.

2) Body education, such as the one achieved with gym and military exercises.

3) Technological education, which collects the general principles and scientific character of the whole production process and at the same time, starts children and adolescents in the management of elementary tools in the various industries."

Safeguarding all the differences in contexts that distance us from the cited publication, we believe that the enhancement of human development in its intellectual, physical and technological dimensions is very fertile towards opening up new horizons for reframing school and teacher's work in now-a-days with impact on other forms of work and understanding of life. From this perspective, Silva (2014: p. 92) claims: "Overcoming the unilateralism of the dominant technical formation, however, is not realized only from the school and its interior, but above all through the work."

It is a fact that individuals do not need to master all knowledge and even that would not be possible in the contemporary world, having in mind the high degree of complexity of production processes and the advancement of knowledge. The different fields of work currently existing, according to their nature, require different skills, knowledge and competences. In many professions dominates sometimes intellectual dimension, sometimes the body dimension or the technical dimension.

However, it is also a fact that the production of life goes beyond work and knowledge for the preparation for 
life in the social, cultural, ethical and esthetic levels are necessary. Faced with crises in social relations among peoples and scarcity of natural resources the dimensions of integral human formation are necessary nowadays. The models of shortened school formation processes which tend to provide early specialized training to individuals, from their basic formation, are inadequate. A formation so disciplinary restricts general formation and directs the option of future workers to a specific field. It happens especially with occupations with less level of complexity.

\section{The Difficulty of Interdisciplinary Implementation in Education Systems}

The issue of interdisciplinary has been part of numerous debates and studies given its importance to the process of teaching and learning. National Curriculum Standards (1996) point out that:

"The interdisciplinary questions the segmentation between different fields of knowledge produced by an approach that does not take into account the interrelationship and influence among them-questions the compartmentalized (disciplinary) vision of reality upon which the school, as known, historically constituted. It refers therefore to a relationship between subjects” (MEC/SEF, 1997, p. 31).

Given the current moment we live in, in which more and more it is necessary to know the elements that allow us to understand the reality around us, it is necessary the constant search for an interdisciplinary approach in the education sector. It is expected to be overcome the fragmented view still present in the pedagogical practice. That condition is required for omnilateral formation of the individual.

The reality lived in our education system collides with the teachers' resistance in wanting to adopt interdisciplinary as a central element of their work, articulating the curricular content and reality. This resistance is not random, but produced as different factors constitute their conceptions, since their initial formation, through their inclusion in education systems and coming to external evaluations, which have reduced increasingly the autonomy of teachers and conditioned him in a non-critical action.

Initial formation that future teachers receive in higher education institutions mostly is markedly disciplinary. The curricula are organized by disciplines and pedagogical political projects fail to articulate them. So, when finishing graduation, the only educational format that they have experienced it was the disciplinary.

Libâneo (2004: p. 22) argues that "for the enrichment of proposals for curricula and methodologies of teacher formation, the learning objectives we expect from students should be, before, goals of teachers' formation.” However, while this matter is not reconsidered in higher education institutions we will have a complicated situation because while teachers are formed along these lines, when entering into the school routine, find themselves obliged to comply with pre-established determinations in schools, especially in relation to external evaluation, since you cannot choose to participate or not participate. In this context, there are complex issues that go beyond the pedagogical practice of teachers and their intentionality.

We will now stick to the determinations of the external evaluation on the teacher's work and its impact on interdisciplinary formation.

Increasingly external evaluations have occupied the pedagogical scenario when evaluating schools setting targets to be reached and making rankings. Internationally we have the Programme for International Student Assessment (Pisa) whose purpose is to conduct a comparative assessment in 15 years students, final age of basic education. Developed and coordinated by the Organization for Economic Development Cooperation (OEDC), each country has a national organization. Given the outcome of the assessment, the OEDC itself carries reports about the performance presented in anticipation of further discussions that will contribute to improving the quality of education.

At the national level we have the external evaluation promoted by the Basic Education Evaluation System (SAEB) or as it is known as "Prova Brasil" (Brazil Exam), established by Ordinance No. 931, March 21, 2005.

The result of the Brazil Exam makes up the Basic Education Development Index (IDEB) which is also linked to the determinations of the Declaration of Compliance to the All for Education Commitment Accession Agreement to the All for Education Commitment (2007), which provides for an increased rate of student performance from 5.3\%, recorded in 2013, to $6.0 \%$ by 2021 (IDEB, 2015), for state, local, federal and private school systems.

This index is generated by gathering data from standardized tests (Brazil Exam or SAEB) and information of school performance (evasion, approval, age distortion/grade). Its main objective is the search for quality as it 
requires that school systems do not waste time reproving their students because the consecutive rebukes generates school evasion and does not ensure best quality performance.

In Brazil, the universalization of education was reached; it is about to promote the guarantee and permanency of students in school with good quality. Thus, this is an important question we really need to achieve.

The question is on the search for the compass between teaching and learning processes that arise from the premises of such assessments that are based on the length of goals.

Inside schools, the reality is not so exciting, because after the definition of curricular content to be objected for the assessment are Portuguese Language and Mathematics, several schools will function in order to direct their pedagogical practice only in connection with the evaluation of these disciplines.

There is an overload in the direction that the teacher gives in his classroom, that now just contemplate these subjects of the official curriculum, leaving in the background all the interdisciplinary work that a priori should be done. In many situations the teacher receives guidance of its management team to only contemplate the disciplines that will be evaluated and to prepare students for the exam.

Once the index generated by IDEB provides for distribution of funds transferred by the federal sphere to the schools, the race for maintaining and/or raising such rates becomes crucial; however, this alienated form of forwarding the teaching and learning process will have catastrophic results.

So we have a problem installed in the reality of many Brazilian schools. Like our education system that belongs to the public municipal level in the state of São Paulo, we believe that this issue also happens in other systems and other Brazilian states. Thus, there is a great challenge to be overcome so that the school can guarantee the integral formation of students.

The situation is complex, because besides the evaluation recommended by the Ministry of Education through the IDEB, there are still those promoted by the state and municipal school systems. In 2011, for example, by acting in a class of 5th grade on elementary School, we conducted three successive external evaluations applied during the months from October to December, of the three evaluative spheres. Yet tacitly, there is an intense collection on the teacher who happens to be blamed for the failure of his class, leaving no time for him to react, think, reflect on the massacre he suffers in everyday school life when faced with the numerous evaluations that he places.

The teacher to teach, besides developing content just for the disciplines of Portuguese Language and Mathematics, starts to focus more on the evaluations than on the process of teaching itself. And to be able to implement an interdisciplinary education in this scenario, he will have to overcome many barriers and be fully aware of his role. However, this does not always happen.

\section{To Think Historically: Possibilities of Knowledge Appropriation as a Result of Human Action}

On the above highlighted concerns, our research and teaching actions have been motivated by concerns about a teacher formation that provides knowledge and experiences of men and women as the historical beings they are and who, therefore, change and are changed by the situations and contexts in which they operate.

Thus, due to the general theme that involves our activity as researchers, which is also in History of Education, we have been encouraged to reflect on the possibilities of integration in the curriculum of early childhood education schools and early years of elementary school aspects local history, so that the History discipline content is presented in school from an early age of the child.

This perspective has led us to propose actions in the mentioned schools so that the teaching of History and its contents are appropriate, both for male and female teachers and male and female students, as result of the action of men and women in the world by which it is possible to understand the social conditions in which we live.

In this sense, the teaching of History and their contents provide a reading of the world and the relationships that are established not as something finished, but as something that raises and requires the action of people for their integration into the world as subjects.

However, before we even think of proposing a work with school children, it is necessary that, first, the teachers to experience situations that provide conditions that they also take ownership of this idea on teaching History and their contents. We are not demanding that such teachers of early childhood education schools and early years of elementary school are experts in History, if only because such formation is not a requirement for teaching in such schools. However, it is important that all teachers to think historically, such as a History teacher, to 
help their students, at the beginning of schooling, to acquire such a tool. By the way, Schmidt and Cainelli (2009: p. 34) state that:

"The History teacher helps the student to acquire the tools necessary to learn to think historically, the know-how, the well-know, throwing the History germs. He is responsible for teaching the student how to capture and enhance the diversity of the sources and historical points of view, leading him to rebuild, for adduction, the route of the historical narrative."

Therefore, it is about the recovery of aspects of the historical path of men and women who, in addition to a linear narrative of facts or dates, refer them to the aspects of their experiences, giving them a sense of belonging in society, so a sense of person who needs to know such a society to lie in it critically.

According to Castro (2012), it has been observed that there is a tendency in education to proposal of projects on how to materialize the knowledge within the school disciplines, particularly in the field of study known as the history of education, more precisely, in the history of school disciplines.

To Marandino (2004: p. 95), the same trend has been observed about researches that seek to analyze educational processes involving the domain and knowledge of teaching arising from social and cultural experience, common sense and practice, fundamental to development of individuals.

More recent researches turn to the study of aspects of the school culture, analyzing the practices, rituals and values present in their routine. Such reflections have for granted the idea that school is a knowledge production space and, so, another conception of knowledge structures, resulting from the search for a wider and more flexible rationality, able to handle the multiplicity and diversity of human knowledge (Tardif, 2002).

Still, according to Marandino (2004: p. 95), “[...] many studies have been made on the issue of transformation of scientific knowledge into school knowledge.”

In this sense, Marandino (2004: pp. 95-96) states that, in the field of teaching, specifically in the field of teaching of mathematics:

“[...] Chevallard (1991, p. 214) states that "The transpositives processes-teaching and, more generally, institutional-are, one imagines, the essential spring of knowledge's life, of its dissemination and its functionality adequate". For this author, transpositive manipulation of knowledge is a sine qua non condition for the functioning of societies. In his view, the changes that knowledge suffers in teaching are fundamental, and the appreciation of pure knowledge production, at the expense of necessary manipulations that occur in the socialization process, suggests the impossibility of the functioning of societies."

Regarding the history of knowledge field, the absence of such manipulations also suggests the neglect that society has with their constitutional processes of knowledge, which is quite evident when, for example, when teaching History in schools, very little is considered about the manipulations of socialization processes of knowledge of history, by way of traces that indicate aspects of local history.

The local history is inserted in a larger History, which, at the same time, determines it and to it is determinative and in this sense, the belief we have is that, in the curriculum of schools, including the Early Childhood Education schools and the initial years of Primary Education, aspects of local history should be known by teachers to then be inserted in the curriculum to be worked out.

According to Bittencourt (2004: p. 168), "the local history has been indicated as necessary for teaching because it allows understanding the student's surrounding, identifying the past always present in various living spaces—school, home, community, work and leisure—and also to situate the significant problems of present history."

Finally, we highlight the importance of proposing possibilities that also teachers think historically, from the point of view that here we seek to do, that is, drawing attention to and seeking the unveiling of a forgotten culture that has prevented school childhood — early childhood education and early years of elementary school—to resume, to deepen, to invest, in which is its specific function, in other words, the promotion of actions for learning that leads to the humanization of children; it means to us, seek reflections that resets the praxis cycle by man in all of life production processes, in our case, at the time of childhood, thus distanced from the pseudo-knowledge resulted of the conditions imposed on him by the school within our society.

\section{Final Considerations}

As one can see, in our activities in teachers' formation, both initial in teachers' formation course and in continu- 
ing education in schools, we have centered efforts for a interdisciplinary formation of teachers, beyond a disciplinary formation, considering that knowledge to a omnilateral formation requires the conjunction of knowledge in order to hope a better understanding of all things and relations present in society. So, in school curricula and curricular matrices, interdisciplinary may contribute to the formation of a more complete individual, able to withstand the investees of high productivity and exacerbated and predatory consumption, recognizing himself as historical subjects.

From this perspective, the learning objectives we expect from the students should be, before, goals of teacher formation. However, while this issue is not rethought, since formation of teachers, we will have a situation where teachers, when step into the school routine, will be required to meet pre-established determinations in schools, especially in relation to external evaluation, since you cannot choose or not to participate. In the case of Brazilian public schools, we see an overload in the direction of what the teacher must give priority in their classroom, and then just a few disciplines of the official curriculum have been worked as Portuguese Language and Mathematics, leaving in the background all the interdisciplinary work that a priori should be done. In many situations the teacher receives guidance of its management team so that he only contemplates the disciplines to be assessed externally.

Considering these aspects, we have been worrying to propose actions in the mentioned schools so that the teaching of History and its contents are appropriate, both for male and female teachers and male and female students, as result of the action of men and women in the world by which it is possible to understand the social conditions in which we live. Therefore, it is about the recovery of aspects of the historical path of men and women who, in addition to a linear narrative of facts or dates, refers them to the aspects of their experiences in an interdisciplinary perspective, which should be recovered through the educational processes in various levels of education in order to give people a sense of belonging in society, thus a sense of a individual who needs to know such society to lie in it critically.

\section{References}

Agamben, G. (2010). O que o contemporâneo? e outros ensaios. Chapecó, SC: Argos.

Bittencourt, C. M. F. (2004). Ensino de História: Fundamentos e métodos. São Paulo: Cortez-(Coleção Docência em Formação).

Castro, R. M. de. (2012). A história da Didática em instituições de formação de professores no Brasil (1827-2011)—Fase I: Fontes para a pesquisa. 21f. Projeto de pesquisa (Regular)—Faculdade de Filosofia e Ciências—Unesp/Marília, Marília.

IDEB. (2015). Ministério da Educação e Cultura. IDEB: Como melhorar os índices. http://portal.mec.gov.br/index.php?option=com content\&view=article\&id=273\&Itemid=345

Libâneo, J. C. (2004). A didática e a aprendizagem do pensar e do aprender: A Teoria Histórico-cultural da Atividade e a contribuição de Vasili Davydov. Revista Brasileira de Educação, n. 27, 5-24. http://dx.doi.org/10.1590/S1413-24782004000300002

Marandino, M. (2004). Transposição ou recontextualização? Sobre a produção de saberes na educação em museus de ciências. Revista Brasileira de Educação, n. 26, 95-108. http://dx.doi.org/10.1590/S1413-24782004000200008

Marx, K., \& Engels, F. (2004). Textos sobre educação e ensino (4th ed.). São Paulo: Centauro.

MEC/SEF. (1997). Parâmetros Curriculares Nacionais (PCNs). Introdução. Ensino Fundamental. Brasília: MEC/SEF.

Rios, T. A. (2008). Compreender e ensinar: Por uma docência da melhor qualidade (7th ed.). São Paulo: Cortez.

Schmidt, M. A., \& Cainelli, M. (2009). Ensinar História. Pensamento e ação na sala de aula (2nd ed.). São Paulo: Scipione.

Silva, V. P. da (2014). Formação de professores na perspectiva da filosofia da práxis: Quem educa o educador? In S. Miller, M. V. Barbosa, \& S. G. L. Mendonça (Eds.), Educação e humanização: As perspectivas da teoria histórico-cultural (pp. 83-96). Jundiaí: Paco Editorial.

Tardif, M. (2002). Saberes docentes e formação profissional. Tradução de Francisco Pereira. Petrópolis: Vozes. 